DOI: https://doi.org/10.47405/mjssh.v5i7.449

\begin{tabular}{|c|c|}
\hline 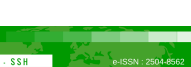 & Malaysian Journal of Social Sciences and Humanities (MJSSH) \\
\hline Malaysian Journal of & Volume 5, Issue 7, July 2020 \\
\hline $\begin{array}{l}\text { Humanitises } \\
\text { (MJ - SSH) }\end{array}$ & e-ISSN : 2504-8562 \\
\hline- & $\begin{array}{l}\text { Journal home page: } \\
\text { www.msocialsciences.com }\end{array}$ \\
\hline
\end{tabular}

\title{
Work-Family Conflict and Psychological Health Among Nurses: A Preliminary Observation
}

\author{
Suzana Mohd Hanifa', Zanariah Ismail'1, Saodah Ahmad ${ }^{1}$, Zarinah Arsat ${ }^{1}$ \\ 1Department of Human Development and Family Studies, Faculty of Human Ecology, \\ Universiti Putra Malaysia (UPM) \\ Correspondence: Suzana Mohd Hanifa (suzanahaziq@gmail.com)
}

\begin{abstract}
Nursing is a female-dominated profession and is commonly considered as a stressful and challenging job. The nature of the nurses' work, which is highly demanding, brings about difficulties in balancing work and family life, further resulting in work-family conflict. Apart from workplace stressors, workfamily conflict has been identified as one of the factors that can threaten nurses' psychological health. This literature review thus sought to identify the factors associated with nurses' experience of workfamily conflict and its consequences to their psychological health. Accordingly, this literature review found that nurses' work characteristics, namely, shift work, job demand and individual factors, significantly influence work-family conflict, which may in turn affect their psychological health in several ways. Future research should focus on positive conditions or resource-based perspectives that can help nurses in reducing work-family conflict and enhancing their health and well-being.
\end{abstract}

Keywords: nurses, work-family conflict, psychological health

\section{Introduction}

According to the International Council of Nurses, a nurse refers to an individual who has completed basic nursing courses and is qualified and authorized by the professional bodies in his or her country to promote good health and provide direct care for the sick (WHO, 2017). In most countries, nursing is a female-dominated profession and makes up the largest workforce in the healthcare industry (Aiken, Sloane, Bruyneel, Van den Heede, \& Sermeus, 2013; DeCola \& Riggins, 2010).

It is well known that nursing is a highly demanding profession because the nature of the nurses' work involves excessive workloads (McVicar, 2003), emotional demands (Cho, Park, Jeon, Chang \& Hong 2014), irregular shift working (Matheson, O’Brien, \& Reid, 2014; Perrucci et al., 2007; Tahghighi, Rees, Brown, Breen \& Hegney, 2017) and poor work environment (Aiken et al., 2013).

Exposure to different types of job stressors puts nurses at risk of having poor psychological health (Jenaro, Flores, Orgaz, \& Cruz, 2011; Tyson \& Pongruengphant, 2004), thereby bringing about negative outcomes to their work productivity and performance, such as, providing lower quality of care to patients (Burke, Koyuncu, \& Fiksenbaum, 2010), less work engagement (Kanten \& Ulker, 2014), higher incidence of medical errors (Suzuki et al., 2004) and job dissatisfaction (Burke, Koyuncu, \& Fiksenbaum, 2010). Employing nurses with poor psychological health also negatively affects the healthcare organization as they may demonstrate absenteeism (Daouk-Öyry, Anouze, 
Otaki, Dumit, \& Osman, 2014; Davey, Cummings, Newburn-Cook, \& Lo, 2009; Jenaro et al., 2011; Roelen et al., 2014) and higher turnover rates (Chan, Tam, Lung, Wong \& Chau, 2013).

Due to their stressful and challenging profession, nurses face difficulties in balancing their work and family life, therefore experiencing work-family conflict. Apart from workplace stressors, work-family conflict has been identified as one of the factors that have a major effect on nurses' psychological health (Mauno \& Ruokolainen, 2015; Yildrim \& Aycan, 2008). Given that nurses' psychological health is vital to the healthcare industry, the objectives of this literature review is to identify the factors which contribute to work-family conflict among nurses and its subsequent effect on their psychological health.

\section{Literature Review}

\section{Work-Family Conflict}

Work-family conflict refers to a form of inter-role conflict which occurs when a person's involvement in the work domain makes it difficult for him or her to comply with the demands of the family domain (Greenhaus \& Beutell, 1985). Research on work-family conflict in the nursing population has been vastly discussed in the literature. In comparison to other lines of work, nurses encounter more challenges in managing their work and non-work activities due to their job's demanding and stressful characteristics. In fact, a few studies have shown that nurses experience higher work-family conflict than other professionals such as school teachers and managers in the private sectors (Cho et al., 2014).

A study conducted by Grzywacz, Frone, Brewer, and Kovner (2006) involving 1213 nurses in the USA reported that more than $50 \%$ of their sample experienced work-family conflict. Such finding is similar to that of an earlier study by Burke and Greenglass (1999) which reported that nurses who worked in the hospital experienced greater work-family conflict. In Malaysia, some studies also showed that nurses who work in the public hospitals experience different levels of work-family conflict. Specifically, nurses in Malaysia have been observed to experience medium inter-role conflict (Said, 1997; Wong, 1997) as well as high-intensity conflict (Ahmad, 1999).

Work-family conflict, which is the negative aspect of work-family interaction, has always been the center of the discussions in the related literature as it has significant adverse effects on individuals, families, and organizations (Mauno, Ruokolainen, \& Kinnunen, 2015). In the work-family literature, work-family conflict can be explained in terms of its nature, sources, and direction (Kelloway, Gottlieb, \& Barham, 1999). Specifically, work-family conflict is a bidirectional construct which is classified into work interference with family and family interference with work. These two constructs are different from one another mainly due to their respective antecedents and consequences (Byron, 2005).

Based on a meta-analytic review, the sources of work-family conflict can be categorized into workrelated, non-work or family-related (Byron, 2005; Michel, Kotrba, Mitchelson, Clark, \& Baltes, 2011) and dispositional sources (Allen et al., 2012; Michel, Clark, \& Jaramillo, 2011). In other metaanalyses, contextual factors and organizational support, such as flexible work arrangements (Allen, Johnson, Kiburz, \& Shockley, 2013), family-friendly work environment (Mesmer-Magnus \& Viswesvaran, 2006), work-family specific support such as supervisor and organizational support (Kossek, Pichler, Bodner, \& Hammer, 2011), and social support (French, Dumani, Allen, \& Shockley, 2017) significantly predicted work-family conflict. The different kinds of sources may act as stressors to individuals, resulting in various types of work-family conflict, namely, time-based conflict, strainbased conflict and behavior-based conflict (Greenhaus \& Beutell, 1985). 


\section{Factors Which Contribute To Work-Family Conflict In Nurses}

In relation to the nursing profession, past studies have revealed that the characteristics of the nurses' work, such as shift work and excessive workloads, are among the factors that contribute to their experience of work-family conflict.

\section{a. Shift work}

Shift work is one of the main work characteristics within the nursing profession. It is a form of work arrangement that has been defined as a non-standard working hour that is outside the normal or traditional work time (i.e., $8 \mathrm{am}-5 \mathrm{pm}$ ) or day (i.e., Monday-Friday) (Rosiello \& Mills, 2015; Perrucci et al., 2007). Shift work has been identified as an antecedent or predictor of work-family conflict among nurses (Mauno et al., 2015; Yildirim \& Aycan, 2008). Earlier studies have likewise demonstrated that nurses who worked on a shift basis reported experiencing higher work-family conflict compared to the non-shift workers (Grzywacz et al., 2006; Mauno et al., 2015). In terms of the direction and dimension of conflict, shift work is considered a significant source of work-to-family conflict as it may bring about time- and strain-based conflict (Greenhaus \& Beutell, 1985).

The types of shift work also have consequences on work-family conflict. Camerino et al. (2010) examined the effects of four different types of work schedule among 664 nurses in Italy, namely, regular day work, irregular day work, shiftwork without nights, and shiftwork with nights, on workfamily conflict. They found that the different work schedules influenced work-family conflict differently. In another study, Tai et al. (2014) reported that married nurses in Taiwan who worked on non-night and rotation shifts experienced poor family functioning compared to those who were working during the day. Similarly, Asiedu, Annor, Amponsah-Tawiah, and Dartey-Baah (2018) found that long working hours and weekend schedules were associated with higher levels of work-to-family conflict among nurses in Ghana.

Similar to other countries, work characteristics have been found to crucially influence work-family conflict among nurses in Malaysia. A recent qualitative study by Sabil, Abu, Kasuma, and Lizzan (2016) suggested that shift work is one of the main factors affecting work-family conflict among nurses in the public hospitals. In another study, Nurumal et al. (2017) reported that working in fixed shifts significantly affected nurses' work-life balance, unlike those working in rotational or multiple shifts. One of the possible reasons for the negative consequences of shift work on work-family relationship may be the limited time alotted to carrying out family responsibilities and socializing with friends (Rosiello \& Mills, 2015).

However, a number of other studies have argued that shift work does not significantly affect workfamily conflict. For example, the study by Fujimoto, Kotani, and Suzuki (2008) reported that working night shifts did not have a significant effect on the conflict between work and child care. In another study, Lembrechts, Dekocker, Zanoni, and Pulignano (2015) found that irregular work schedules did not have a significant unique influence on work-family conflict. Further, a study by Wong (1997) reported no significant difference between the work-family conflict experienced by nurses who worked on shift schedule and that by those who worked during normal hours. This has led some authors to suggest that the effect of shift work on nurses' well-being and quality of life depends on contextual and individual factors (Tahghighi et al., 2017).

\section{b. Nurses' Job Demand and Work-Environment}

Nurses' job demand and excessive workload have also been found to significantly predict their experience of work-family conflict. Some studies have shown that workload (Ghislieri, Gatti, Molino, \& Cortese, 2017; Yildirim \& Aycan, 2008) and overtime hours (Lembrechts et al., 2015) increase nurses' work-to- family conflict. In another study, Cho et al. (2014) reported that nurses' higher work pace was also significantly associated with work-family conflict. Similarly, a study by Simon, Kümmerling, and Hasselhorn (2004) indicated that nurses' quantitative demands, including increased workload and being pressured to work overtime, were significant predictors of time- and strain-based 
work-family conflict among 27,603 registered nurses in eight European countries. In another study, Cortese, Colombo, and Ghislieri (2010) reported that job demand and emotional charge played significant roles in predicting work-family conflict among 351 professional nurses in Italy.

Apart from shiftwork and job demand, nurses also experience work-family conflict differently depending on where they work. As a professional caregiver, the common workplace settings for nurses are hospitals, public/community health clinics, home healthcare and nursing homes. A study conducted in Japan by Yamaguchi, Inoue, Harada, and Oike (2016) showed that work-family conflict experienced by nurses varied across three care settings, namely, hospitals, home healthcare, and nursing homes. They observed that nurses who worked in the hospitals experienced significantly more work interference with family than those employed at a home healthcare or nursing home.

\section{c. Individual Factors}

Although the past literature has shown that gender does not influence work-family conflict (Byron, 2005; Eby, Casper, Lockwood, Bordeaux, \& Brinley, 2005), women seem to be more vulnerable to work-family conflict due to their responsibility in the work and family domains. In view of this, Zurlo, Vallone, and Smith (2020) conducted a study to explore gender differences in the perceived level of work-family conflict among 450 male and female nurses working in five public hospitals in Italy. The result of their study showed that female nurses experienced higher work-family conflict than their male counterparts. Apart from gender, other factors, such as gender role orientation, have also been found to predict work-family conflict. A study by Namayandeh, Yaacob, and Juhari (2010) revealed that married female nurses in Iran who adopted a more egalitarian gender role attitude had higher work inteference with family conflict than their counterparts. Further, Ahmad (1999) examined work-family conflict experienced by 125 pairs of nurses and their husbands. The study found a significant negative relationship between husbands' gender role orientations and wives' experience of work-family conflict. Finally, demographic characteristics, such as age, health, and family responsibilities, have been shown to be significant determinants of nurses' family-to-work conflict (Asiedu et al., 2018; Burke \& Greenglass, 1999; Unruh, Raffenaud, \& Fottler, 2016), but not of work-to-family conflict.

\section{The Consequences Of Work-Family Conflict}

The consequences of work-family conflict have been discussed extensively in several meta-analyses. Accordingly, the outcomes of work-family conflict may be classified into those which are related to work, family, general health and well-being (Allen, Herst, Bruck, \& Sutton, 2000; Amstad, Meier, Fasel, Elfering, \& Semmer, 2011; Michel, Mitchelson, Kotrba, LeBreton, \& Baltes, 2009) or employee development (Liao, Lau, Hui, \& Kong, 2019). Other studies have also found that workfamily conflict is associated with unhealthy behaviors, such as, overeating, smoking, problematic drinking, sleep deficiency (Jacobsen et al., 2014; Shukri, Jones, \& Conner, 2018) and sickness absence (Jansen et al., 2006).

In the work-family literature, psychological health has frequently been investigated as an outcome of work-family conflict. A few meta-analyses have examined the consequences of work-family conflict in the context of psychological health. Kossek and Ozeki (1998) found that work-family conflict was negatively associated with job satisfaction and life satisfaction. Similar results were reported by Mesmer-Magnus and Viswesvaran (2005), in that, work-to-family conflict and family-to-work conflict had significant correlations with life satisfaction and health. By the same token, Greenhaus, Allen, and Spector (2006) reviewed the negative consequences of work-family conflict on the multiple dimensions of health and well-being. Accordingly, they found that health and well-being can be categorized in terms of psychological health, health-related behavior and physical health. In another meta-analysis, Amstad et al. (2011) further explained that the forms of general well-being, namely, life satisfaction, psychological strain and anxiety, are classified as domain-unspecific outcomes in the work-family research. 


\section{Related Theories}

This study identified two theories, namely, the role theory and conservation of resource (COR) theory, which explain the relationship between work-family conflict and psychological health. The role theory developed by Kahn et al. (1964) posits that an individual has limited amounts of attention, time and energy. Hence, when a person is involved in multiple roles that are incompatible, he/she may experience inter-role conflict, which can further bring about negative consequences on his/her health and well-being.

In contrast, the COR theory stipulates that individuals seek to acquire, maintain and allocate resources (Hobfoll, 2001). Based on this theory, resources are defined as conditions, personal characteristics, energy and objects that assist individuals in coping with stressful events and challenging situations (Hobfoll, 1989). Work-family conflict is a stressful condition in which the demands at work deplete the resources that an individual need to meet his/her family roles. Thus, the COR theory suggests that resource loss due to the inter-role conflict could jeopardize individual's health and well-being in several ways.

\section{The Relationship Between Work-Family Conflict and Psychological Health Among Nurses}

The consequences of work-family conflict on nurses' psychological health are frequently explained in the context of work-related psychological health (e.g., job satisfaction and burnout), family-related psychological health (e.g., family satisfaction) and general psychological well-being (e.g., life satisfaction and depression). Needless to say, most of the empirical literature on the relationship between work-family conflict and psychological health among nurses are from cross-sectional studies (Gisler et al., 2018).

In terms of work-related psychological health, burnout is regarded as the most discussed outcome of work-family conflict for the last five years (Gisler et al., 2018). In fact, many authors agree that workfamily conflict is an important predictor of burnout among nurses (Boamah \& Laschinger, 2016; Braunstein-Bercovitz, Frish-Burstein, \& Benjamin, 2012; Goong, Xu, \& Li, 2016). As regards the dimensions of burnout, work-family conflict has been found to be significantly associated with emotional exhaustion among nurses in Italy (Camerino et al., 2010). In another study, Simha, Elloy, and Huang (2014) found that work-family conflict had a positive influence on the relationship between depersonalization and cynicism. In contrast, Leineweber, Chungkham, Westerlund, Tishelman, and Lindqvist (2014) found that high work-family conflict increased the risk of emotional exhaustion, but not of depersonalization and personal accomplishment. As to the direction of conflict, a study conducted by Asiedu et al. (2018) reported that burnout is more related to family-to-work conflict than to work-to-family conflict among nurses in Ghana.

The literature has also indicated that work-family conflict has a significant effect on other workrelated psychological health constructs such as job satisfaction and job stress. Specifically, Farhadi, Sharifian, Feili, and Shokrpour (2013) found that work-family conflict (both directions) was positively related to job stress among nurses. In another study, Roulin, Mayor, and Bangerter (2014) found that work-family conflict significantly predicted job satisfaction at the individual level among 1,547 nurses working in 17 hospitals in Switzerland. Further, Buonocore and Russo (2013) investigated the association between work-family conflict and job satisfaction among 171 Italian nurses. The study found that time-based conflict and strain-based conflict were negatively associated with job satisfaction.

Furthermore, there have been mixed findings on family-related psychological health outcomes of work-family conflict in the nursing population. Burke and Greenglass (1999) found that work-family conflict (both directions) was negatively associated with family satisfaction among 686 hospital-based nurses. In contrast, Farhadi et al. (2013) observed that work-family conflict (both directions) was not significantly associated with family satisfaction among the nurses in Iran. 
Work-family conflict has also been associated with domain-unspecific outcomes including psychological distress, depression and life satisfaction among nurses. A study by Burke and Greenglass (1999) involving 686 hospital-based nurses revealed that work-family conflict (both directions) was associated with greater psychological distress among nurses. Sharma, Dhar, and Tyagi (2016) likewise reported that work-family conflict had a direct negative relationship with the psychological health (i.e., mental health, social functioning and vitality) of female nurses in India. Similarly, Charkhabi, Sartori, and Ceschi (2016) found that work-to-family conflict had greater effects on mental health than family-to-work conflict among nurses in Iran.

Additionally, work-family conflict has been found to be a risk factor for nurses' depressive symptoms. A study conducted by Hao, Wu, Liu, Li, and $\mathrm{Wu}$ (2015) on 824 nurses in China showed that workfamily conflict (both directions) was positively related to depressive symptoms. Work-family conflict was also found to be significantly associated with depressive symptoms among nurses in a community hospital in the USA (Zhang, Duffy, \& Cattillero, 2017).

The work-family research has also found evidence that work-family conflict impacts the overall satisfaction of life among nurses. Accordingly, Yildrim and Aycan (2007) found that work-to-family conflict was associated with lower life satisfaction. In contrast, other studies failed to find significant negative relationships between conflict in the work-family interface and life satisfaction among nurses (Farhadi et al., 2013; Xu \& Song, 2016). One possible explanation for this inconsistent results is that work-family conflict has been found to more significantly predict work-related psychological wellbeing (e.g., burnout and job satisfaction) than general psychological well-being (e.g., life satisfaction and depression) among registered nurses (Xu \& Song, 2016).

A number of studies have also examined the effect of work-family conflict on Malaysian nurses' psychological health. Rashid, Nordin, Omar, and Ismail (2013) studied 689 nurses in public hospitals, and found that work-family conflict was negatively related to overall satisfaction (i.e., well-being, family and job satisfaction). Similar findings were reported by Husin and Noor (2007), in that, workfamily conflict contributed to mental health (i.e., psychological strain) and job satisfaction among 254 married nurses in government hospitals and public health care centers in the East Coast of Peninsular Malaysia.

\section{Conclusion}

This study reviewed the factors associated with nurses' work-family conflict and its subsequent effect on their psychological health. In conclusion, this study found that nurses' work characteristics are significant in influencing work-family conflict. Further, work-family conflict was identified as a stressful condition that may be a risk factor for nurses' psychological health in several ways. As nurses are employed in a female-dominated profession and make up the largest workforce in the healthcare industry, ensuring their psychological health is vital for organizational effectiveness and in providing a high quality of patient care. Realizing that nurses' psychological health is essential in enhancing their capabilities to improve system delivery, there is a need to ensure that they receive support in both the work and family domains. Future research should focus on positive conditions or resource-based perspectives that could help nurses in reducing work-family conflict and in enhancing their health and well-being. In view of this, contextual resouces from the work environment and personality resources should be considered as important variables in future studies.

\section{References}

Aiken, L. H., Sloane, D. M., Bruyneel, L., Van den Heede, K., \& Sermeus, W. (2013). Nurses' reports of working conditions and hospital quality of care in 12 countries in Europe. International Journal of Nursing Studies, 50(2), 143-153. doi:10.1016/j.ijnurstu.2012.11.009.

Ahmad, A. (1999). Gender role orientation of husbands and work-family conflict of wives in dual- 
earner families. Journal of Social Science and Human, 7(1), 1-9.

Allen, T. D., Herst, D. E. L., Bruck, C. S., \& Sutton, M. (2000). Consequences associated with workto-family conflict: A review and agenda for future research. Journal of Occupational Health Psychology, 5(2), 278-308. doi:10.1037//1076-899B.5.2.278.

Allen, T. D., Johnson, R. C., Kiburz, K. M., \& Shockley, K. M. (2013). Work-family conflict and flexible work arrangements: Deconstructing flexibility. Personnel Psychology, 66(2), 345-376. doi:10.1111/peps.12012.

Allen, T. D., Johnson, R. C., Saboe, K. N., Cho, E., Dumani, S., \& Evans, S. (2012). Dispositional variables and work-family conflict: A meta-analysis. Journal of Vocational Behavior, 80, 17 26. doi:10.1016/j.jvb.2011.04.004.

Amstad, F. T., Meier, L. L., Fasel, U., Elfering, A., \& Semmer, N. K. (2011). A meta-analysis of work-family conflict and various outcomes with a special emphasis on cross-domain versus matching-domain relations. Journal of Occupational Health Psychology, 16(2), 151-169. doi:10.1037/a0022170.

Asiedu, E. E. A., Annor, F., Amponsah-Tawiah, K., \& Dartey-Baah, K. (2018). Juggling family and professional caring: Role demands, work-family conflict and burnout among registered nurses in Ghana. Nursing Open, 5(4), 611-620. doi:10.1002/nop2.178.

Boamah, S. A., \& Laschinger, H. (2016). The influence of areas of worklife fit and work-life interference on burnout and turnover intentions among new graduate nurses. Journal of Nursing Management, 24(2), E164-E174. doi:10.1111/jonm.12318.

Braunstein-Bercovitz, H., Frish-Burstein, S., \& Benjamin, B. A. (2012). The role of personal resources in work-family conflict: Implications for young mothers' well-being. Journal of Vocational Behavior, 80(2), 317-325. doi:10.1016/j.jvb.2011.10.003.

Buonocore, F., \& Russo, M. (2013). Reducing the effects of work-family conflict on job satisfaction: The kind of commitment matters. Human Resource Management Journal, 23(1), 91-108. doi:10.1111/j.1748-8583.2011.00187.x.

Burke, R. J., Koyuncu, M., \& Fiksenbaum, L. (2010). Burnout, work satisfactions and psychological well-being among nurses in Turkish hospitals. Europe's Journal of Psychology, 6(1). doi:10.5964/ejop.v6i1.172

Burke, R. J., \& Greenglass, E. R. (1999). Work-family conflict, spouse support, and nursing staff wellbeing during organisational restructuring. Journal of Occupational Health Psychology, 4(4), 327-336. doi:10.1037/1076-8998.4.4.327.

Byron, K. (2005). A meta-analytic review of work-family conflict and its antecedents. Journal of Vocational Behavior, 67(2), 169-198. doi:10.1016/j.jvb.2004.08.009.

Camerino, D., Sandri, M., Sartori, S., Conway, P. M., Campanini, P., Costa, G., ... Medica, S. (2010). Shiftwork, work-family conflict among Italian nurses, and prevention efficacy. Chronobiology International, 27(5), 1105-1123. doi:10.3109/07420528.2010.490072.

Chan, Z. C. Y., Tam, W. S., Lung, M. K. Y., Wong, W. Y., \& Chau, C. W. (2013). A systematic literature review of nurse shortage and the intention to leave. Journal of Nursing Management, 21(4), 605-613. doi:10.1111/j.1365-2834.2012.01437.x.

Charkhabi, M., Sartori, R., \& Ceschi, A. (2016). Work-family conflict based on strain: The most hazardous type of conflict in Iranian hospitals nurses. SA Journal of Industrial Psychology, 42(1), 1-10. doi:10.4102/sajip.v42i1.1264.

Cho, S. H., Park, M., Jeon, S. H., Chang, H. E., \& Hong, H. J. (2014). Average hospital length of stay, nurses' work demands, and their health and job outcomes. Journal of Nursing Scholarship, 46(3), 199-206. doi:10.1111/jnu.12066.

Cortese, C. G., Colombo, L., \& Ghislieri, C. (2010). Determinants of nurses' job satisfaction: The role of work-family conflict, job demand, emotional charge and social support. Journal of Nursing Management, 18(1), 35-43. doi:10.1111/j.1365-2834.2009.01064.x.

Daouk-Öyry, L., Anouze, A. L., Otaki, F., Dumit, N. Y., \& Osman, I. (2014). The JOINT model of nurse absenteeism and turnover: A systematic review. International Journal of Nursing Studies, 51(1), 93-110. doi: 10.1016/j.ijnurstu.2013.06.018.

Davey, M. M., Cummings, G., Newburn-Cook, C. V., \& Lo, E. A. (2009). Predictors of nurse absenteeism in hospitals: A systematic review. Journal of Nursing Management, 17(3), 312330. doi:10.1111/j.1365-2834.2008.00958.x.

DeCola, P. R., \& Riggins, P. (2010). Nurses in the workplace: Expectations and needs. International 
Nursing Review, 57(3), 335-342. doi:/10.1111/j.1466-7657.2010.00818.x.

Eby, L. T., Casper, W. J., Lockwood, A., Bordeaux, C., \& Brinley, A. (2005). Work and family research in IO/OB: Content analysis and review of the literature (1980-2002). Journal of Vocational Behaviour, 66(1), 124-197. doi:10.1016/j.jvb.2003.11.003.

Farhadi, P., Sharifian, R., Feili, A., \& Shokrpour, N. (2013). The effects of supervisors' supportive role, job stress, and work-family conflicts on the nurses' attitudes. Health Care Manager, 32(2), 107-122. doi:10.1097/HCM.0b013e31828ef5e7.

French, K. A., Dumani, S., Allen, T. D., \& Shockley, K. M. (2017). A meta-analysis of work - family conflict and social support. Psychological Bulletin. Advance online publication. doi:10.1037/bul0000120.

Fujimoto, T., Kotani, S., \& Suzuki, R. (2008). Work-family conflict of nurses in Japan. Journal of Clinical Nursing, 17(24), 3286-3295. doi:10.1111/j.1365-2702.2008.02643.x.

Ghislieri, C., Gatti, P., Molino, M., \& Cortese, C. G. (2017). Work-family conflict and enrichment in nurses: Between job demands, perceived organisational support and work-family backlash. Journal of Nursing Management, 25, 65-75. doi: 0.1111/jonm.12442.

Gisler, S., Omansky, R., Alenick, P. R., Tumminia, A. M., Eatough, E. M., \& Johnson, R. C. (2018). Work-life conflict and employee health: A review. Journal of Applied Biobehavioral Research, 23(4), 1-46. doi:10.1111/jabr.12157.

Goong, H., Xu, L., \& Li, C. -Y (2016). Effects of work-family-school role conflicts and role-related social support on burnout in Registered Nurses: A structural equation modelling approach. Journal of Advanced Nursing, 72(11), 2762-2772. doi:10.1111/jan.13029.

Greenhaus, J. H., Allen, T. D., \& Spector, P. E. (2006). Health consequences of work-family conflict: The dark side of the work-family interface. In P. L. Perrewé \& D. C. Ganster (Eds.), Research in occupational stress and well-being Vol. 5: Employee Health, Coping and Methodologies, (pp.61-98). Elsevier Ltd. doi:10.1016/S1479-3555(05)05002-X.

Greenhaus, J. H., \& Beutell, N. J. (1985). Sources of conflict between work and family roles. Academy of Management Review, 10(1), 76-88. doi:10.5465/AMR.1985.4277352.

Grzywacz, J. G., Frone, M. R., Brewer, C. S., \& Kovner, C. T. (2006). Quantifying work-family conflict among registered nurses. Research in Nursing \& Health, 29(5), 414-426. doi:10.1002/nur.20133.

Hao, J., Wu, D., Liu, L., Li, X., \& Wu, H. (2015). Association between work-family conflict and depressive symptoms among Chinese female nurses: The mediating and moderating role of psychological capital. International Journal of Environmental Research and Public Health, 12(6), 6682-6699. doi:10.3390/ijerph120606682.

Hobfoll, S. E. (1989). Conservation of resources: A new attempt at conceptualizing stress. American Psychologist, 44(3), 513-524. doi:10.1037/0003-066X.44.3.513.

Hobfoll, S. E. (2001). The influence of culture, community, and the nested-self in the stress process: Advancing conservation of resources theory. Applied Psychology, 50(3), 337-421. doi:10.1111/1464-0597.00062.

Husin, R., \& Noor, N. M. (2007). Work-family conflict, coping and well-being in nurses. In The Third International Research Colloquium: Research In Malaysia and Thailand (pp. 131-163). International Islamic University Malaysia.

Jacobsen, H. B., Reme, S. E., Sembajwe, G., Hopcia, K., Stoddard, A. M., Kenwood, C., ... Buxton, O. M. (2014). Work-family conflict, psychological distress, and sleep deficiency among patient care workers. Workplace Health \& Safety, 62(7), 282-291. doi:10.1177/216507991406200703.

Jansen, N. W., Kant, I. J., van Amelsvroot, L. G. P. M., Kristensen, T. S., Swaen, G. M. H., \& Nijhuis, F. J. N. (2006). Work-family conflict as a risk factor for sickness absence. Occupational and Environmental Medicine, 63(7), 488-494. doi:10.1136/oem.2005.024943.

Jenaro, C., Flores, N., Orgaz, M. B., \& Cruz, M. (2011). Vigour and dedication in nursing professionals: Towards a better understanding of work engagement. Journal of Advanced Nursing, 67(4), 865-875. doi:10.1111/j.1365-2648.2010.05526.x.

Kahn, R. L., Wolfe, D. M., Quinn, R. P., Snoek, J. D., \& Rosenthal, R. A. (1964). Organisational stress: Studies in role conflict and ambiguity. New York: Wiley.

Kanten, P., \& Ulker, F. (2014). The effects of mental health problems of nurses and doctors on their professional commitment and work engagement levels. Mediterranean Journal of Social Sciences, 5(19), 476-493. doi:10.5901/mjss.2014.v5n19p476. 
Kelloway, E. K., Gottlieb, B. H., \& Barham, L. (1999). The source, nature, and direction of work and family conflict: A longitudinal investigation. Journal of Occupational Health Psychology, 4(4), 337-346. doi:10.1037/1076-8998.4.4.337.

Kossek, E. E., \& Ozeki, C. (1998). Work-family conflict, policies, and the job-life satisfaction relationship: A review and directions for organisational behavior human resources research. Journal of Applied Psychology, 83(2), 139-149. doi:10.1037/0021-9010.83.2.139.

Kossek, E. E., Pichler, S., Bodner, T., \& Hammer, L. B. (2011). Workplace social support and workfamily conflict: A meta-analysis clarifying the influence of general and work-family-specific supervisor and organizational support. Personnel Psychology, 64(2), 289-313. doi:10.1111/j.1744-6570.2011.01211.x.

Leineweber, C., Chungkham, H. S., Westerlund, H., Tishelman, C., \& Lindqvist, R. (2014). Hospital organizational factors influence work-family conflict in registered nurses: Multilevel modeling of a nation-wide cross-sectional survey in Sweden. International Journal of Nursing Studies, 51(5), 744-751. doi:10.1016/j.ijnurstu.2013.09.010.

Lembrechts, L., Dekocker, V., Zanoni, P., \& Pulignano, V. (2015). A study of the determinants of work-to-family conflict among hospital nurses in Belgium. Journal of Nursing Management, 23(7), 898-909. doi:10.1111/jonm.12233.

Liao, E. Y., Lau, V. P., Hui, R. T. Y., \& Kong, K. H. (2019). A resource-based perspective on workfamily conflict: Meta-analytical findings. Career Development International, 24(1), 37-73. doi:10.1108/CDI-12-2017-0236.

Matheson, A., O'Brien, L., \& Reid, J. A. (2014). The impact of shiftwork on health: A literature review. Journal of Clinical Nursing, 23(23-24), 3309-3320. doi:10.1111/jocn.12524.

Mauno, S., \& Ruokolainen, M. (2015). Does organizational work-family support benefit temporary and permanent employees equally in a work-family conflict situation in relation to job satisfaction. Journal of Family Issues. doi: 10.1177/0192513X15600729.

Mauno, S., Ruokolainen, M., \& Kinnunen, U. (2015). Work-family conflict and enrichment from the perspective of psychosocial resources: Comparing Finnish healthcare workers by working schedules. Applied Ergonomics, 48, 86-94. doi:10.1016/j.apergo.2014.11.009.

McVicar, A. (2003). Workplace stress in nursing: A literature review. Journal of Advanced Nursing, 44(6), 633-642. doi:10.1046/j.0309-2402.2003.02853.x.

Mesmer-Magnus, J. R., \& Viswesvaran, C. (2005). Convergence between measures of work-to-family and family-to-work conflict: A meta-analytic examination. Journal of Vocational Behavior, 67(2), 215-232. doi:10.1016/j.jvb.2004.05.004.

Mesmer-Magnus, J. R., \& Viswesvaran, C. (2006). How family-friendly work environments affect work/family conflict: A meta-analytic examination. Journal of Labor Research, 27(4), 555-574. doi:10.1007/s12122-006-1020-1.

Michel, J. S., Clark, M. A., \& Jaramillo, D. (2011). The role of the Five Factor Model of personality in the perceptions of negative and positive forms of work-nonwork spillover: A meta-analytic review. Journal of Vocational Behavior, 79(1), 191-203. doi:10.1016/j.jvb.2010.12.010.

Michel, J. S., Kotrba, L. M., Mitchelson, J. K., Clark, M. ., \& Baltes, B. B. (2011). Antecedents of work -family conflict: A meta-analytic review. Journal of Organizational Behaviour, 32(5), 689-725. doi:10.1002/job.695.

Michel, J. S., Mitchelson, J. K., Kotrba, L. M., LeBreton, J. M., \& Baltes, B. B. (2009). A comparative test of work-family conflict models and critical examination of work-family linkages. Journal of Vocational Behavior, 74(2), 199-218. doi:10.1016/j.jvb.2008.12.005.

Namayandeh, H., Yaacob, S. N., \& Juhari, R. (2010). The effect of gender role orientation on work interference with family (WIF) and family interference with work (FIW) among married female nurses in Shiraz-Iran. Asian Culture and History, 2(2), p165. doi:10.5539/ach.v2n2p165.

Nurumal, M. S., Makabe, S., Che Jamaludin, F. I., Yusof, F.M., H., Aung, K. T., \& Kowitlawakul, Y. (2017). Work-life balance among Teaching Hospital nurses in Malaysia. Global Journal of Health Science, 9(9), 81. doi:10.5539/gjhs.v9n9p81.

Perrucci, R., MacDermid, S., King, E., Tang, C.-Y., Brimeyer, T., Ramadoss, K., wanberg, J. (2007). The significance of shift work: Current status and future directions. Journal of Family and Economic Issues, 28(4), 600-617. doi:10.1007/s10834-007-9078-3.

Rashid, W. E.W., Nordin, M.S., Omar, A., \& Ismail, I. (2013). Work/family conflict: The link between self-Esteem and satisfaction outcomes. Procedia - Social and Behavioral Sciences, 65, 
564-569. doi:10.1016/j.sbspro.2012.11.166.

Roelen, C., van Rhenen, W., Schaufeli, W., van der Klink, J., Mageroy, N., Moen, B., Pallesen, S. (2014). Mental and physical health-related functioning mediates between psychological job demands and sickness absence among nurses. Journal of Advanced Nursing, 70(8), 1780-1792. doi:10.1111/jan.12335.

Rosiello, R.M. and Mills, M.J. (2015). Shiftwork as Gendered and Its Impact on Work-Family Balance. In Mills, M. J. (Ed), Gender and the Work-Family Expereince: An Intersection of Two Domains (pp 251-270). Springer International Publishing.

Roulin, N., Mayor, E., \& Bangerter, A. (2014). How to satisfy and retain personnel despite job-market shortage: Multilevel predictors of nurses' job satisfaction and intent to leave. Swiss Journal of Psychology, 73(1), 13-24. doi:10.1024/1421-0185/a000123.

Sabil, F., Abu, H., Kasuma, J., \& Lizzan, N. (2016). Identifying Work-Family Conflict among Nurses: A Qualitative Study. 3rd International Conference on Business and Economics, (September), 108-120. doi:10.15405/epsbs.2016.11.02.11.

Said, A.M. (1997). Work-family conflict and coping behaviour: A study of married nurses. (Unpublished master thesis) University Putra Malaysia.

Sharma, J., Dhar, R. L., \& Tyagi, A. (2016). Stress as a mediator between work-family conflict and psychological health among the nursing staff: Moderating role of emotional intelligence. Applied Nursing Research, 30, 268-275. doi: 10.1016/j.apnr.2015.01.010.

Shukri, M., Jones, F., \& Conner, M. (2018). Relationship between work-family conflict and unhealthy eating: Does eating style matter? Appetite, 123, 225-232. doi:10.1016/j.appet.2017.12.027.

Simha, A., Elloy, D. F., \& Huang, H. C. (2014). The moderated relationship between job burnout and organizational cynicism. Management Decision, 52(3), 482-504. doi:10.1108/MD-08-20130422 .

Simon, M., Kümmerling, A., \& Hasselhorn, H. M. (2004). Work-home conflict in the European nursing profession. International Journal of Occupational and Environmental Health, 10(4), 384-391. /doi:10.1179/oeh.2004.10.4.384.

Suzuki, K., Ohida, T., Kaneita, Y., Yokoyama, E., Miyake, T., Harano, S., Uchiyama, M. (2004). Mental health status, shift work, and occupational accidents among hospital nurses in Japan. Journal of Occupational Health, 46(6), 448-454. doi:10.1539/joh.46.448.

Tai, S. Y., Lin, P. C, L., Chen, Y. M., Hung, H. C., Pan, C. H., Pan, S. M., Wu, M. T. (2014). Effects of marital status and shift work on family function among registered nurses. Industrial Health, 52(4), 296-303. doi:10.2486/indhealth.2014-0009.

Tahghighi, M., Rees, C. S., Brown, J. A., Breen, L. J., \& Hegney, D. (2017). What is the impact of shift work on the psychological functioning and resilience of nurses? An integrative review. Journal of Advanced Nursing. doi:10.1111/jan.13283.

Tyson, P. D., \& Pongruengphant, R. (2004). Five-year follow-up study of stress among nurses in public and private hospitals in Thailand. International Journal of Nursing Studies, 41(3), 247254. doi:10.1016/S0020-7489(03)00134-2.

Unruh, L. Y., Raffenaud, A., \& Fottler, M. (2016). Work-family conflict among newly licensed registered nurses: A structural equation model of antecedents and outcomes. Journal of Healthcare Management, 61(2), 129-145. doi:10.1097/00115514-201603000-00010.

World Health Organization (WHO). (2017). Nursing and Midwifery in the History of the World Health Organization 1948-2017. World Health Organization. Geneva, Switzerland.

Wong Y. C. (1997). Interrole conflict and social support: A study of married women nurses. (Unpublished Master Thesis).University Putra Malaysia.

$\mathrm{Xu}$, L., \& Song, R. (2016). Influence of work-family-school role conflicts and social support on psychological wellbeing among registered nurses pursuing advanced degree. Applied Nursing Research, 31, 6-12. doi:10.1016/j.apnr.2015.12.005.

Yamaguchi, Y., Inoue, T., Harada, H., \& Oike, M. (2016). Job control, work-family balance and nurses' intention to leave their profession and organization: A comparative cross-sectional survey. International Journal of Nursing Studies, 64, 52-62. doi:10.1016/j.ijnurstu.2016.09.003.

Yildirim, D., \& Aycan, Z. (2008). Nurses' work demands and work-family conflict: A questionnaire survey. International Journal of Nursing Studies, 45(9), 1366-1378. doi:10.1016/j.ijnurstu.2007.10.010.

Zhang, Y., Duffy, F. J., \& Cattillero, R. E. (2017). Do sleep disturbances mediate the association 
DOI: https://doi.org/10.47405/mjssh.v5i7.449

between work-family conflict and depressive symptoms among nurses? A cross-sectional study. Journal of Psychiatric Mental Health, 24(8), 620-628. doi:10.1111/jpm.12409.

Zurlo, M. C., Vallone, F., \& Smith, A. P. (2020). Work-family conflict and psychophysical health conditions of nurses: Gender differences and moderating variables. Japan Journal of Nursing Science, , 1-12. doi:10.1111/jjns.12324. 